DOI: https://doi.org/10.24843/JFU.2019.v08.i01.p01 pISSN: 2301-7716; eISSN: 2622-4607

Jurnal Farmasi Udayana, Vol 8, No 1, Tahun 2019, 1-6

\title{
Penggunaan Antikoagulan Oral Baru pada Fibrilasi Atrium
}

\author{
Krisnayanti, M.W. ${ }^{1}$, Dewi, N.P.U.S. ${ }^{1}$, Amandari, I.G.A.A.E. ${ }^{1}$, Sarasmita, M.A. ${ }^{1}$ \\ 'Program Studi Farmasi Fakultas Matematika dan Ilmu Pengetahuan Alam, Universitas Udayana, Jalan Kampus \\ Unud-Jimbaran, Jimbaran-Bali, Indonesia 80364. Telp./Fax.703837 \\ E-mail:windakrisna@yahoo.com
}

\begin{abstract}
ABSTRAK
Fibrilasi atrium (FA) adalah salah satu jenis aritmia yang paling sering terjadi dan prevalensinya terus meningkat di dunia. Karakteristik FA berupa aktivasi elektrik atrium yang tidak teratur dan kontraksi atrium yang tidak terkoordinasi. Antikoagulan oral adalah agen antitrombotik unggul telah lama digunakan pada pasien dengan FA. Warfarin (antagonis vitamin K) adalah antikoagulan yang paling banyak digunakan untuk pencegahan stroke pada pasien dengan FA. Namun terdapat beberapa keterbatasan dalam penggunaan warfarin dan seiring dengan berkembangnya pengobatan FA, dikembangkan juga berbagai antikoagulan baru dari kelas yang berbeda dengan masing-masing keunggulan dan kerugiannya. Dabigatran, rivaroxaban, dan apixaban adalah contoh jenis antikoagulan baru yang memiliki beberapa perbedaan dalam tatalaksana FA.
\end{abstract}

Kata kunci: Antikoagulan, Fibrilasi Atrium, Warfarin

\begin{abstract}
Atrial fibrillation $(A F)$ is one of the most common types of arrbythmias and its prevalence is increasing in the world. FA characteristics consist of irregular atrial electrical activation and uncoordinated atrial contraction. Oral anticoagulants are superior antithrombotic agents have long been used in patients with $\mathrm{F} A$. Warfarin (vitamin $\mathrm{K}$ antagonist) is the most widely used anticoagulant for stroke prevention in patients with $\mathrm{FA}$. There are, however, some limitations in the use of warfarin and as the treatment of FA progresses, new anticoagulants of different classes have been developed with their respective advantages and disadvantages. Dabigatran, rivaroxaban, and apixaban are examples of new types of anticoagulants that have some differences in FA management therapy.
\end{abstract}

Keywords: Anticoagulant, Atrial Fibrillation, Warfarin

\section{PENDAHULUAN}

Fibrilasi atrium (FA) adalah salah satu jenis aritmia yang paling sering terjadi dan prevalensinya terus meningkat di dunia. Karakteristik dari pasien dengan FA dapat berupa aktivasi elektrik atrium yang tidak teratur dan kontraksi atrium yang tidak terkoordinasi. Prevalensi terus meningkat seiring dengan pertambahan usia, FA diderita oleh $1-2 \%$ penduduk dunia dengan rata-rata usia 40-50 tahun dan sekitar 5-15\% penderita diantaranya berusia diatas 80 tahun (January et al., 2014). FA adalah faktor risiko munculnya kejadian tromboemboli yang menghasilkan lima kali lipat lebih besar risiko stroke dibandingkan irama sinus (Agustini, dkk., 2013).

Antikoagulan telah lama digunakan pada pasien dengan FA. Antikoagulan oral adalah agen antitrombotik unggul tetapi kurang dimanfaatkan karena ketakutan akan terjadinya perdarahan dan ketidakpastian apakah pasien akan mendapatkan keuntungan dari penggunaan antikoagulan (Pinzon, dkk., 2017). Pemberian antikoagulan memerlukan pemantauan secara berkala mengingat risiko perdarahan yang ditimbulkan, baik ringan maupun berat (Roveny, 2015). Warfarin merupakan obat antikoagulan antagonis vitamin $\mathrm{K}$ yang diindikasikan untuk mengatasi 
DOI: https://doi.org/10.24843/JFU.2019.v08.i01.p01 pISSN: 2301-7716; eISSN: 2622-4607

Jurnal Farmasi Udayana, Vol 8, No 1, Tahun 2019, 1-6

profilaksis dan pengobatan pada komplikasi tromboembolik yang berhubungan dengan FA. Penggunaan warfarin mempunyai efektifitas tinggi dalam menurunkan kejadian stroke pada $62 \%$ pasien dengan FA (Agustini, dkk., 2013).

Penggunaan terapi warfarin memiliki keterbatasan seperti indeks terapi sempit dimana hal ini menyebabkan banyaknya interaksi antara makanan dengan obat, sehingga diperlukan monitoring laboratorium secara berkala. Namun monitoring tersebut merepotkan pasien dan membutuhkan biaya sehingga menyebabkan penggunaan terapi warfarin menjadi kurang dari dua pertiga dari keseluruhan pasien dengan FA. Seiring dengan berkembangnya pengobatan FA, dikembangkan juga berbagai antikoagulan baru dari kelas yang berbeda dengan masing-masing keunggulan dan kerugiannya. Kehadiran antikoagulan baru, seperti rivaroxaban, dabigatran, apixaban, edoxaban dapat menjadi alternatif baru pada tatalaksana FA (Nursalim dan Setiabudi, 2012).
Fibrilasi atrium merupakan suatu gangguan irama jantung yang memiliki karakteristik antara lain seperti interval RR yang tidak teratur yakni tidak adanya pola repetitif pada ektrokardiogram (EKG), gambaran gelombang $\mathrm{P}$ yang tidak jelas pada EKG, serta siklus atrial (apabila terlihat) yakni interval antara dua aktivasi atrial sangat bervariasi sebesar $<200 \mathrm{~ms}$ atau $>300$ kali per menit (Nursalim dan Setiabudi, 2012).

Terdapat 5 tipe FA secara klinis yang dibedakan berdasarkan durasi dan presentasinya yaitu: FA yang pertama kali terdiagnosis, FA paroksimal, FA persisten, FA persisten lama (long standing persistent), dan FA permanen. Klasifikasi FA tidak selalu eksklusif satu sama lainnya, dimana pasien dapat mengalami beberapa episode FA persisten, dan di waktu yang lain terkadang FA paroksismal, ataupun sebaliknya. Sehingga berdasarkan dari manifestasi klinis yang paling dominan maka pasien dapat dimasukkan ke dalam salah satu dari kategori tersebut (Perki, 2014).

\section{FIBRILASI ATRIUM}

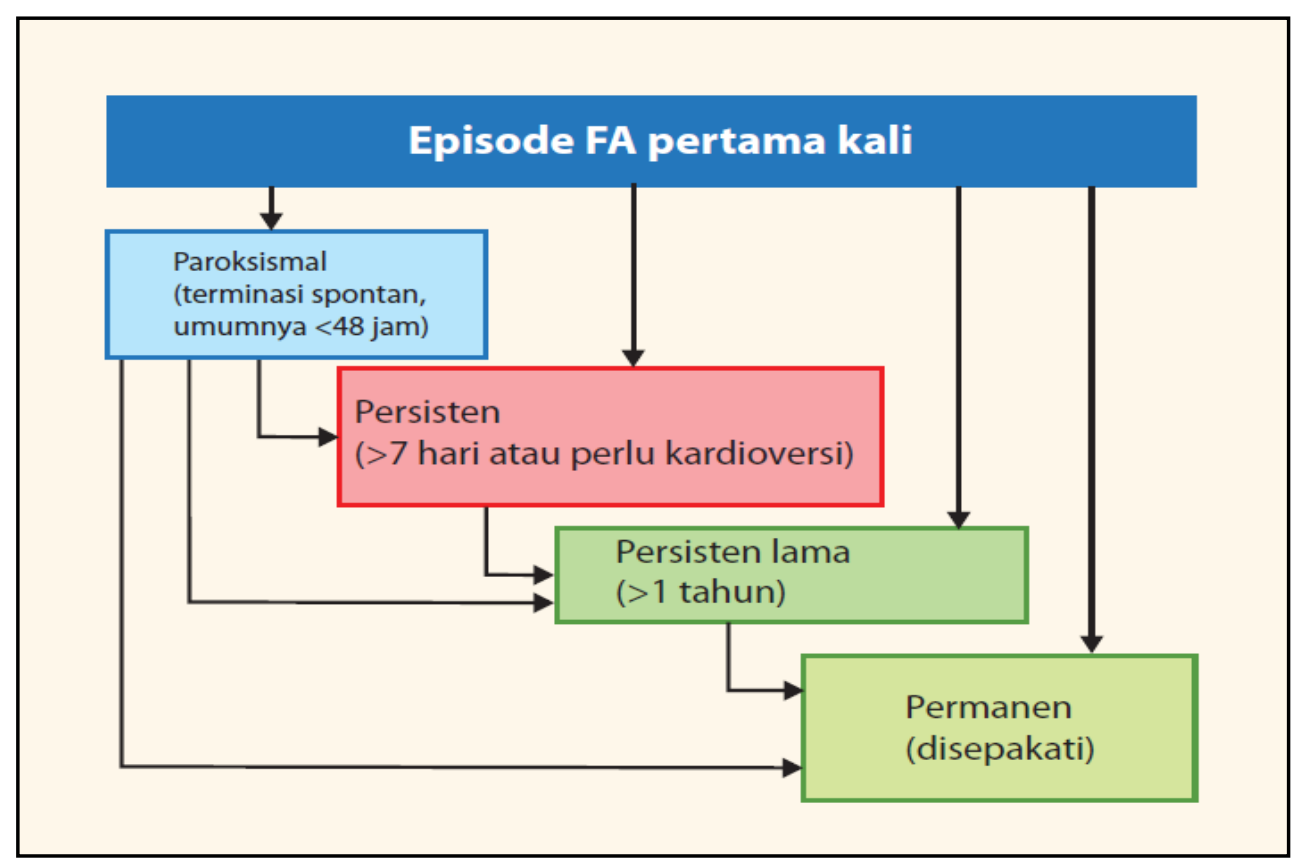

Gambar 1. Klasifikasi FA menurut waktu presentasinya (Perki, 2014). 
DOI: https://doi.org/10.24843/JFU.2019.v08.i01.p01 pISSN: 2301-7716; eISSN: 2622-4607

Jurnal Farmasi Udayana, Vol 8, No 1, Tahun 2019, 1-6

Tabel 1. Karakteristik Warfarin dan AKB (Roveny, 2015; Yakobus, 2017).

\begin{tabular}{|c|c|c|c|c|c|}
\hline Obat & Warfarin & Rivaroxaban & Dabigatran & Apixaban & Edoxaban \\
\hline Mekanisme & $\begin{array}{c}\text { Mengganggu } \\
\text { sintesis faktor } \\
\text { koagulasi terkait } \\
\text { vitamin } \mathrm{K} \\
\end{array}$ & $\begin{array}{c}\text { Menghambat } \\
\text { faktor } \mathrm{Xa}\end{array}$ & $\begin{array}{l}\text { Menghambat } \\
\text { thrombin }\end{array}$ & $\begin{array}{c}\text { Menghambat } \\
\text { faktor Xa }\end{array}$ & $\begin{array}{c}\text { Menghambat } \\
\text { faktor Xa }\end{array}$ \\
\hline Sediaan & Oral & Oral & Oral & Oral & Oral \\
\hline Pengaturan dosis & $\begin{array}{c}\text { Tergantung } \\
\text { INR } \\
\text { individual }\end{array}$ & Sesuai $\mathrm{CrCl}$ & $\begin{array}{c}\text { Sesuai } \mathrm{CrCl} \text {, } \\
\text { umur }\end{array}$ & $\begin{array}{l}\text { Sesuai } \mathrm{CrCl} \text {, } \\
\text { berat badan, } \\
\text { umur }\end{array}$ & Tidak perlu \\
\hline Onset & 36-72 jam & 2-4 jam & 0,5-2 jam & 1-3 jam & 1-3 jam \\
\hline Waktu paruh & 20-60 jam & 9-13 jam & $12-14$ jam & 8-15 jam & 9-11 jam \\
\hline Farmakokinetik & $\begin{array}{c}\text { Tidak } \\
\text { terprediksi }\end{array}$ & Stabil & Stabil & Stabil & Stabil \\
\hline Interaksi obat & $\begin{array}{l}\text { CYP2C9,- } \\
3 \mathrm{~A} 4,-1 \mathrm{~A} 2 \\
\end{array}$ & $\begin{array}{l}\text { CYP 3A4, } \\
\text { inbibitor p-gp }\end{array}$ & Inhibitor $p-g p$ & CYP3A4 & $\begin{array}{l}\text { CYP3A4, } \\
\text { inhibitor } p-g p\end{array}$ \\
\hline Pemantauan & $\begin{array}{l}\text { Dibutuhkan } \\
\text { rutin }\end{array}$ & $\begin{array}{l}\text { Tidak } \\
\text { dibutuhkan } \\
\text { rutin }\end{array}$ & $\begin{array}{c}\text { Tidak } \\
\text { dibutuhkan } \\
\text { rutin }\end{array}$ & $\begin{array}{c}\text { Tidak } \\
\text { dibutuhkan } \\
\text { rutin }\end{array}$ & $\begin{array}{c}\text { Tidak } \\
\text { dibutuhkan } \\
\text { rutin }\end{array}$ \\
\hline Eliminasi & $80 \% / 65 \%$ & $60 \%$ & $80 \%$ & $27 \%$ & $40 \%$ \\
\hline Antidotum & $\begin{array}{l}\text { Vitamin K, } \\
\text { FFP, PCC }\end{array}$ & PCC & $\begin{array}{c}\text { PCC, antibody } \\
\text { eksperimetal }\end{array}$ & PCC & PCC \\
\hline
\end{tabular}

*Keterangan:

$\mathrm{CrCl}=$ Creatinine clearance; $\mathrm{CYP3A} 4=$ Cytochrome $\mathrm{P} 450$ 3A4; $\mathrm{p}$-gp $=$ p-glycoprotein $; \mathrm{BB}=$ Berat badan; INR= International normalized ratio; $\mathrm{PCC}=$ Prothrombin complex concentrates.

Tujuan yang ingin dicapai dalam penatalaksanaan FA diantaranya adalah untuk pemeliharaan dan pemulihan irama sinus, sebagai pencegahan terjadinya tromboemboli, mengontrol laju denyut jantung, mengatasi simtom pada pasien dengan FA, sebagai tata laksana optimal untuk penyakit penyerta (kardiovaskular), serta memperbaiki gangguan irama (Nursalim dan Setiabudi, 2012). Terapi antitrombotik yang umum digunakan pada pasien dengan FA meliputi terapi antiplatelet dan terapi antitrombotik atau antikoagulan (antagonis vitamin $\mathrm{K}$ ). Warfarin (antagonis vitamin $\mathrm{K}$ ) merupakan antikoagulan yang paling banyak digunakan pada pasien FA untuk mencegah stroke (Perki, 2014).

\section{PERBEDAAN WARFARIN DENGAN ANTIKOAGULAN BARU}

Berbagai antikoagulan baru (AKB) dikembangan seiring dengan berkembangnya pengobatan FA. Antikoagulan tersebut berasal dari kelas yang berbeda-beda dengan masing-masing keunggulan dan kerugiannya. Antikoagulan diharapkan memiliki karakteristik ideal seperti dapat diberikan per oral satu kali sehari untuk meningkatkan kepatuhan terapi, efektif dalam mencegah kejadian tromboembolik, dikenal sifat farmakokinetiknya, lebih jarang menyebabkan perdarahan, dan dapat berinteraksi minimal dengan obat atau makanan (Nursalim dan Setiabudi, 2012).

Warfarin termasuk obat antagonis vitamin $\mathrm{K}$, memiliki beberapa kekurangan, di antaranya onset yang kerja lambat, berinteraksi banyak dengan obat serta makanan, memerlukan pemantauan kontinu, risiko 
DOI: https://doi.org/10.24843/JFU.2019.v08.i01.p01

pISSN: 2301-7716; eISSN: 2622-4607

Jurnal Farmasi Udayana, Vol 8, No 1, Tahun 2019, 1-6

perdarahan pada dosis berlebih dan risiko kejadian trombosis pada dosis suboptimal. Kehadiran AKB seperti rivaroxaban, dabigatran, apixaban, dan edoxaban dapat menjadi alternatif. AKB merupakan antikoagulan dengan respons yang lebih terprediksi, interaksinya minimal, onset kerja cepat, waktu paruh lebih singkat, dapat diberikan pada dosis tetap tanpa pemantauan rutin, serta rasio efikasi atau keamanan lebih baik. Namun, penggunaan AKB masih belum umum di kalangan klinisi. Disamping itu penelitian, strategi, dan standarisasi terapi terkait $\mathrm{AKB}$ masih terbatas dan sejauh ini juga AKB masih difokuskan hanya pada kasus fibrilasi (Nursalim dan Setiabudi, 2012).

\section{ANTIKOAGULAN BARU PADA FIBRILASI ATRIUM \\ RIVAROXABAN}

Rivaroxaban merupakan obat antikoagulan golongan penghambat faktor $\mathrm{Xa}$ oral pertama yang mampu mencegah terjadinya trombogenesis tanpa bantuan kofaktor antitrombin untuk pencegahan stroke pada FA nonvalvular. Rivaroxaban ditoleransi dengan baik pada pasien dewasa yang sehat, dan mampu diperkirakan efek antikoagulannya terjadi pada kisaran dosis 5$80 \mathrm{mg}$ (Nursalim dan Setiabudi, 2012). Pada pasien dengan $\mathrm{FA}$, rivaroxaban digunakan 20 mg sekali sehari dan dikonsumsi bersamaan dengan makanan. Karena obat dieliminasi secara parsial di ginjal, sehingga dosis harus dikurangi menjadi $15 \mathrm{mg}$ satu kali sehari pada pasien dengan $\mathrm{CrCl} 15-50 \mathrm{~mL} /$ menit (Yakobus, 2017).

Berdasarkan penelitian Hori (2012) yang dilakukan di Jepang pada 1.280 pasien dengan FA nonvalvular pada peningkatan risiko stroke. Pasien secara acak menerima terapi $15 \mathrm{mg}$ rivaroxaban sekali sehari atau warfarin yang disesuaikan menurut pedoman pengobatan Jepang. Hasil menunjukkan bahwa tingkat keamanan adalah sebesar $18,04 \%$ per tahun pada pasien yang diobati dengan rivaroxaban dan sebesar $16,42 \%$ per tahun pada pasien dengan warfarin. Tingkat perdarahan intrakranial sebesar $0,8 \%$ dengan rivaroxaban dan 1,6\% dengan warfarin. Selain itu dibandingkan dengan warfarin terdapat kecendrungan kuat untuk pengurangan tingkat stroke dengan rivaroxaban dibandingkan dengan warfarin (Hori, 2012).

\section{DABIGATRAN}

Dabigatran adalah antikoagulan oral golongan penghambat trombin. Dabigatran eteksilat segera dihidrolisasi pada pemberian secara oral yang menjadi bentuk aktifnya yakni dabigatran. Setelah diabsorpsi di saluran gastrointestinal (GI) kemudian konsentrasi plasma tertinggi dicapai dalam waktu 0,5-2 jam, kemudian obat ini akan dibuang lewat ginjal. Waktu paruh dabigatran adalah antara 12-17 jam sehingga obat ini perlu dikonsumsi dua kali dalam sehari. Mula kerja dabigatran relatif cepat, adanya interaksi dengan makanan dan dengan obat lain terjadi lebih sedikit dibandingkan dengan warfarin, serta obat ini tidak memerlukan monitoring laboratorium secara intensif seperti warfarin (Tran, et al., 2011).

Berdasarkan penelitian Aslan (2014) dilakukan dengan membandingkan kelompok pasien yang menggunakan terapi warfarin dengan kelompok terapi dabigatran. Pasien dipilih secara acak terdiri dari 219. Hasil penelitian tersebut menunjukkan bahwa ada perbedaan yang signifikan antar kelompok intervensi (perlakuan) sehubungan dengan stroke iskemik (warfarin sebesar 6,8\%, dabigatran $110 \mathrm{mg}$ sebesar $5,2 \%$, dan

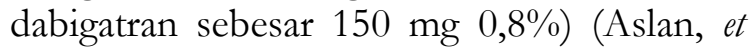
al., 2014).

\section{APIXABAN}

Apixaban adalah inhibitor faktor $\mathrm{Xa}$ yang cepat diserap dan memiliki waktu paruh 12 jam. Profil farmakokinetik dan farmakodinamik obat ini dapat diramalkan sehingga tidak diperlukan pemantauan berkala seperti warfarin. Namun apixaban berinteraksi dengan berbagai obat lain karena di metabolisme oleh CYP 450 3A4 (Nursalim dan Setiabudi, 2012). Pada pasien dengan FA, 
DOI: https://doi.org/10.24843/JFU.2019.v08.i01.p01

pISSN: 2301-7716; eISSN: 2622-4607

Jurnal Farmasi Udayana, Vol 8, No 1, Tahun 2019, 1-6

dianjurkan penggunaan dosis apixaban $5 \mathrm{mg}$ dua kali sehari. Dosis yang dikurangi menjadi 2,5 mg sebanyak dua kali sehari dianjurkan pada pasien dengan dua atau lebih kriteria berikut: usia 80 tahun atau lebih, berat badan $60 \mathrm{~kg}$ atau kurang, dan tingkat $\mathrm{CrCl}$ 1,5 $\mathrm{mg} / \mathrm{dL}$ atau lebih tinggi (Yakobus, 2017).

Salah satu studi yang membandingkan efektivitas apixaban dengan warfarin dilakukan oleh Granger, et al. Pada uji klinis tersebut, diamati efektivitas apixaban untuk pencegahan stroke pada 18.201 pasien FA yang memiliki setidaknya satu faktor risiko stroke. Penelitian ini merupakan penelitian berskala besar yang melibatkan pasien FA dengan nilai rerata $\mathrm{CHADS}_{2}$ sebesar 2,1. Dosis apixaban yang digunakan adalah $2 \times 5$ mg sehari dan tablet warfarin diberikan pada dosis $2 \mathrm{mg}$ untuk menghasilkan nilai INR 2,0-3,0 (Nursalim dan Setiabudi, 2012).

Setelah pemantauan selama 1,8 tahun, dilakukan penilaian terhadap parameter primer berupa stroke iskemik, stroke hemoragik, atau emboli sistemik. Kejadian stroke pada kelompok apixaban ditemukan $1.19 \%$, sedangkan pada kelompok warfarin 1,51\%. Hasil ini menunjukkan superioritas apixaban dibandingkan warfarin dalam mencegah stroke dengan penurunan $\mathrm{RR}$ sebesar 25\%. Selain itu, apixaban juga dinilai lebih aman, yang dapat dilihat dari angka perdarahan yang lebih rendah dibandingkan warfarin sebesar $31 \%$ (Nursalim dan Setiabudi, 2012).

Penelitian Ogawa (2014) yang juga mempelajari keamanan dan efektivitas apixaban pada 222 penyandang FA . Subjek dikelompokkan ke dalam kelompok apixaban 2,5 $\mathrm{mg}$ dan $5 \mathrm{mg}$, atau kelompok warfarin (dosis disesuaikan untuk mencapai INR 2,03,0). Setelah 12 minggu dilakukan dilihat parameter seperti kejadian stroke, emboli sistemik, dan kematian. Pada kelompok apixaban, tidak dijumpai stroke, emboli sistemik, maupun kematian. Sementara pada kelompok warfarin ditemukan 2 strokeiskemik, 1 perdarahan subarak-noid, dan tidak ada kematian (Ogawa, et al., 2011).

\section{EDOXABAN}

Edoxaban merupakan obat antagonis non-vitamin $K$ yang bersifat cepat dan selektif. Edoxaban dapat digunakan sekali sehari secara oral. Pada subyek yang sehat, dosis tunggal edoxaban menghasilkan konsentrasi plasma puncak dalam waktu pemberian 1-2 jam. Penggunaan dosis edoxaban untuk dosis sekali sehari sebesar 15-150 mg. Edoxaban sebagian besar diserap di saluran pencernaan bagian atas, dan bioavailabilitas oralnya sekitar $62 \%$. Makanan tidak mempengaruhi total paparan dari edoxaban. Waktu paruh eliminasi terminal pada subyek sehat berkisar antara 10-14 jam, dengan akumulasi minimal setelah pengulangan dosis sekali sehari hingga dosis $120 \mathrm{mg}$. Mekanisme klirensnya melibatkan jalur ginjal dan non-ginjal. Faktor intrinsik seperti usia, jenis kelamin dan ras, tidak mempengaruhi farmakokinetik edoxaban setelah mempertimbangkan fungsi ginjal (Yakobus, 2017).

Pemodelan dan simulasi farmakokinetik yang dilakukan pada penelitian sebelumnya menunjukkan bahwa pasien dengan berat badan rendah, disfungsi ginjal sedang hingga berat, atau penggunaan bersamaan dengan inhibitor P-glikoprotein kuat harus memiliki dosis edoxaban yang dikurangi sebesar 50\%. Pemberian edoxaban secara oral menghasilkan perubahan yang cepat dalam biomarker antikoagulan, dengan efek puncak pada penanda antikoagulasi (seperti anti-FXa), PT dan aPTT terjadi dalam 1-2 jam. Meskipun tidak ada obat penawar khusus untuk edoxaban namun saat ini tersedia agen hemostatik untuk membalikkan efek antikoagulannya (Yakobus, 2017).

Penelitian Steffel (2016) mengenai efektifitas dan keamanan edoxaban dibandingkan dengan warfarin pada pasien dengan FA yang dinilai memiliki risiko jatuh yang tinggi. Hasil penelitian menunjukkan terapi dengan edoxaban menghasilkan penurunan risiko yang lebih besar pada 
DOI: https://doi.org/10.24843/JFU.2019.v08.i01.p01

pISSN: 2301-7716; eISSN: 2622-4607

Jurnal Farmasi Udayana, Vol 8, No 1, Tahun 2019, 1-6

kejadian perdarahan berat dan semua penyebab kematian dibandingan dengan warfarin (Steffel, 2016).

\section{KESIMPULAN}

Penemuan berbagai antikoagulan baru seperti dabigatran, rivaroxaban, apixaban, dan edoxaban adalah alternatif yang dapat dipertimbangkan untuk mengatasi beberapa keterbatasan dengan terapi warfarin. Namun penggunaan dan pengalaman klinis antikoagulan baru tersebut masih terbatas dan ada kemungkinan munculnya efek samping sehingga harus digunakan secara hati-hati.

\section{UCAPAN TERIMAKASIH}

Penulis mengucapkan terimakasih kepada seluruh Dosen Jurusan Farmasi Universitas Udayana atas bantuan, arahan, dan masukannya selama penelitian berlangsung.

\section{DAFTAR PUSTAKA}

Aslan, O., Y. T. Yaylali, S. Yildirim, M. Yurtdas, H. Senol, M. Ugur-Yildiz and M. Ozdemi. 2014. Dabigatran Versus Warfarin in Atrial Fibrilation. Clinic and Applied Thrombosis/Hemostatis:1-6.

Hori, M. 2012. Rivaroxaban vs. Warfarin in Japanese Patients With Atrial Fibrillation. Circulation Journal. 76: 21042111.

January, C. T, Wann, Alpert, Calkins H., Cigarroa J. E, Cleveland J. C, et al. 2014. AHA/ACC/HRS guideline for the management of patients with atrial fibrilation. Circulation. 129:1-124.
Nursalim, A. dan Setiabudi, E. 2012. Efektivitas Antikoagulan Baru Dibandingkan dengan Warfarin dalam Mencegah Stroke pada Pasien Atrial Fibrilasi. J Indom Med Assoe. 62(10): 407-411.

Ogawa, S., Shinohara, Y., Kanmuri, K. 2011. Safety and efficacy of the oral direct factor $\mathrm{Xa}$ inhibitor apixaban in japanese patients with non-valvular atrial fibrillation. Circ J. 75:1852-9.

Perki. 2014. Pedoman Tata Laksana Fibrilasi Atrium. Edisi Pertama. Jakarta: Centra Communications

Pinzon, R. T., Astyari, G. A. P. I. B. S., Tarigan, L. 2017. Pola pengobatan antitrombotik pada pasien stroke iskemik dengan fibrilasi atrium berdasarkan skor CHA2DS2-VASc dan skor HAS BLED. Pharmaciana. 7(1): 63-70.

Roveny. 2015. Antikoagulan untuk Stroke Iskemik Kardioemboli. CDK-228. 42(5): 345-349.

Steffel, J. 2016. Edoxaban Versus Warfarin in Atrial Fibrillation Patients at Risk of Falling ENGAGE AF-TIMI 48 Analysis. Journal of the American College of Cardiology. 66(11): 1169-1178.

Tran A, Pharm, D., Ceng-Lai, A. 2011. Dabigatran Etexilate, the first oral anticoagulant available in the united states since warfarin. Cardiology in Review. 19:154-61.

Yakobus, Y. 2017. New Oral Anticoagulants for Atrial Fibrillation. Jumal Kedokteran dan Kesehatan Indonesia. 8(2): 102-109 